\title{
Impact Analysis of Changes in Fishery Regulations in the Norton Sound Red King Crab Fishery
}

\author{
BILL NATCHER,${ }^{1}$ JOSHUA GREENBERG ${ }^{2}$ and MARK HERRMANN ${ }^{3}$
}

(Received 24 February 1998; accepted in revised form 22 July 1998)

\begin{abstract}
In 1994, the Norton Sound summer red king crab fishery became the only federally managed Alaska king crab fishery designated as "super-exclusive." The new designation has fundamentally changed this fishery's industrial structure: previously dominated by a highly capitalized, distant-water fleet, it has become a small-scale local fishery. A regional economic input-output model was constructed to evaluate the economic impacts of this "new" fishery on the Nome region. The model results indicate that in 1994 this industry was able to contribute over half a million dollars in income to an economically depressed region of Alaska where few local industries exist and the prospects for developing new industries are dim. Furthermore, model results suggest that the regional economic impact nearly doubles when the contributions of both increased local processing and participation by other western Alaska communities are included in the estimation.
\end{abstract}

Key words: Norton Sound, crab fishery, input-output models, economic impact analysis, regional economic analysis

RÉSUMÉ. En 1994, la pêche estivale au crabe de l'Alaska dans le Norton Sound est devenue l'unique pêche gérée par le gouvernement fédéral portant le label de «super-exclusive». Cette nouvelle désignation a fondamentalement changé la structure industrielle de cette pêcherie. Dominée auparavant par une flotte hauturière fortement capitalisée, elle est devenue une industrie de pêche locale à petite échelle. On a construit un modèle des entrées-sorties économiques de la région afin d'évaluer les retombées économiques de cette «nouvelle» pêcherie sur la région du Norton Sound. Les résultats du modèle indiquent qu'en 1994 cette industrie a réussi à injecter plus d'un demi-million de dollars de revenus dans une région de l'Alaska en pleine crise économique, où existent peu d'industries locales et où les perspectives de création de nouvelles industries sont minimes. De plus, les résultats du modèle suggèrent que les retombées sur l'économie régionale doublent quand on inclut dans les chiffres à la fois l'augmentation de l'industrie de transformation locale et la participation d'autres communautés de l'Alaska occidental.

Mots clés: Norton Sound, industrie du crab, modèles d'entrées-sorties, analyse des retombées économiques, analyse économique régionale

Traduit pour la revue Arctic par Nésida Loyer.

\section{BACKGROUND}

In 1994, the Norton Sound Summer Red King Crab (NSSRKC) fishery was designated "super-exclusive" by the North Pacific Fisheries Management Council (NPFMC). This super-exclusive designation means that any vessel which participates in the Norton Sound fishery is barred from participating in any other federally managed king crab fishery. The change in management designation fundamentally changed the way the NSSRKC fishery is prosecuted. A once highly capitalized, distant-water fleet was replaced by small local vessels primarily from the Nome and Yukon Delta regions. This change not only created direct employment opportunities for local residents but also contributed to the local economy in general.

The fishery for red king crab (Paralithodes camtschaticus) takes place off the southern coast of the
Seward Peninsula, near Nome, Alaska (ADFG, 1994; Figs. 1 and 2). Although the fishery is located in the federally controlled U.S. Exclusive Economic Zone, approximately $32-64 \mathrm{~km}$ offshore, the state of Alaska, through its Board of Fisheries (Board), has the primary management authority. The State's authority is derived from a 1989 cooperative Bering Sea Aleutian Islands (BSAI) king and Tanner crab fishery management plan (FMP) (NPFMC, 1989). Historically, the NSSRKC fishery has been the smallest king crab fishery managed under the FMP. Fishery harvest was approximately $150000 \mathrm{~kg}$ in 1993 and 1994 and $145000 \mathrm{~kg}$ in 1995 . These figures compare, for example, to a Bristol Bay red king crab harvest that has ranged between 3.6 and 9.1 million $\mathrm{kg}$ in the 1990s.

The commercial fishery was initiated in 1977 at the request of local subsistence fishers who had filed a petition

\footnotetext{
${ }^{1}$ Department of Economics, University of Alaska Fairbanks, Fairbanks, Alaska 99775; present address: Department of Agricultural

Economics \& Rural Sociology, Pennsylvania State University, University Park, Pennsylvania 16802, U.S.A.

${ }^{2}$ Department of Natural Resources Management, University of Alaska Fairbanks, Fairbanks, Alaska 99775, U.S.A.

${ }^{3}$ Department of Economics, University of Alaska Fairbanks, Fairbanks, Alaska 99775, U.S.A.; ffmlh@uaf.edu

(C) The Arctic Institute of North America
} 


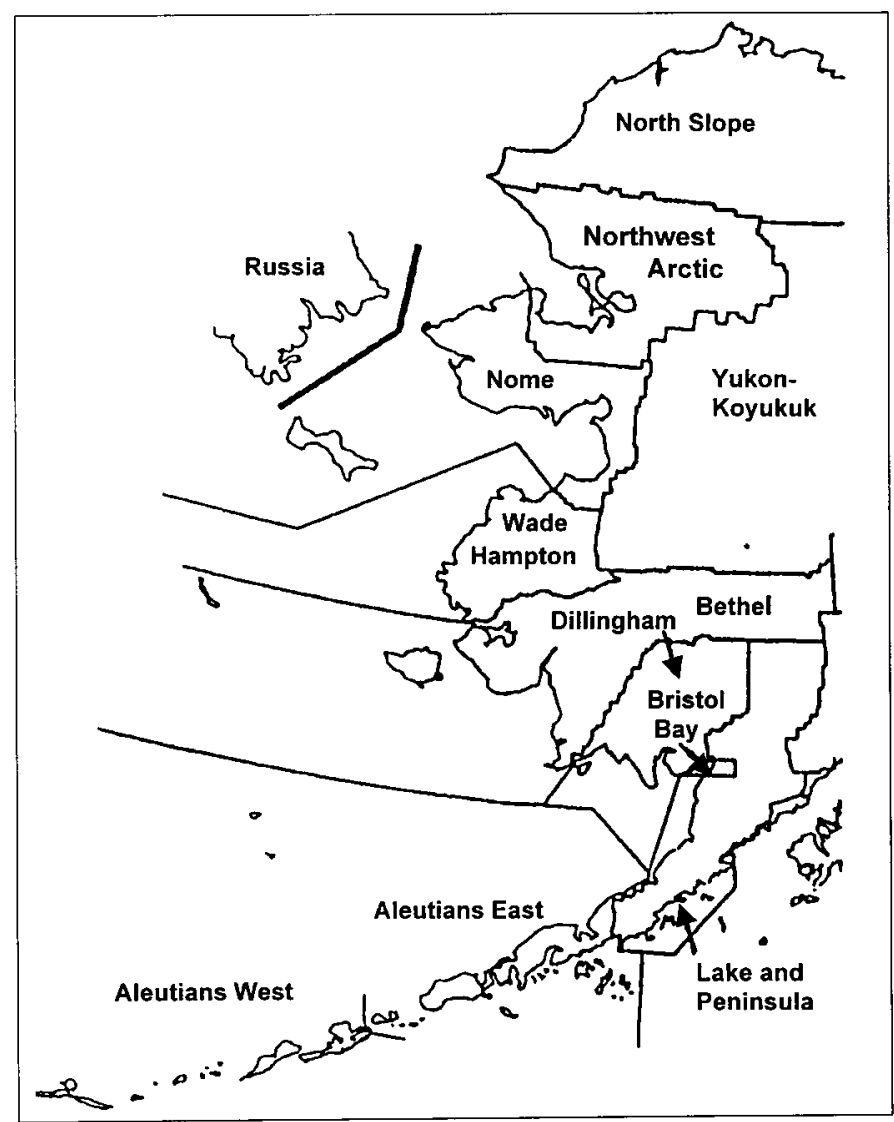

FIG. 1. Western Alaska 1990 U.S. census districts.

with the Board. However, local participation in the fishery did not materialize, as the fishery became dominated by highly capitalized, distant-water crab vessels that participated in other BSAI crab fisheries. Until recently, the fishery was managed on a regulated open access basis. This management changed when the Board designated the fishery as super-exclusive in 1993. The Board cited a host of fishery problems in recommending the management change: an over-capitalized fleet, which creates seasons too short to manage effectively; lack of management precision, which creates harvests significantly over and under the guideline harvest level; and concerns about vessel safety. The change in fishery status was appealed by the Alaska Crab Coalition, which contended that the Board had exceeded its authority under the FMP in designating the fishery as super-exclusive. The appeal was upheld by the U.S. Secretary of Commerce; however, the ruling was sufficiently delayed that fishery participants viewed the fishery as de facto super-exclusive for the 1993 season. The NPFMC reimposed super-exclusive status in 1994.

The adoption of super-exclusive status has led to a fundamental change in the NSSRKC industry. Large catcher-processors exited the fishery and were replaced by small catcher vessels, principally from the Nome and Wade Hampton U.S. census districts of western Alaska (Fig. 1). For example in 1995, 39 vessels from western Alaska participated in the fishery, compared to only one

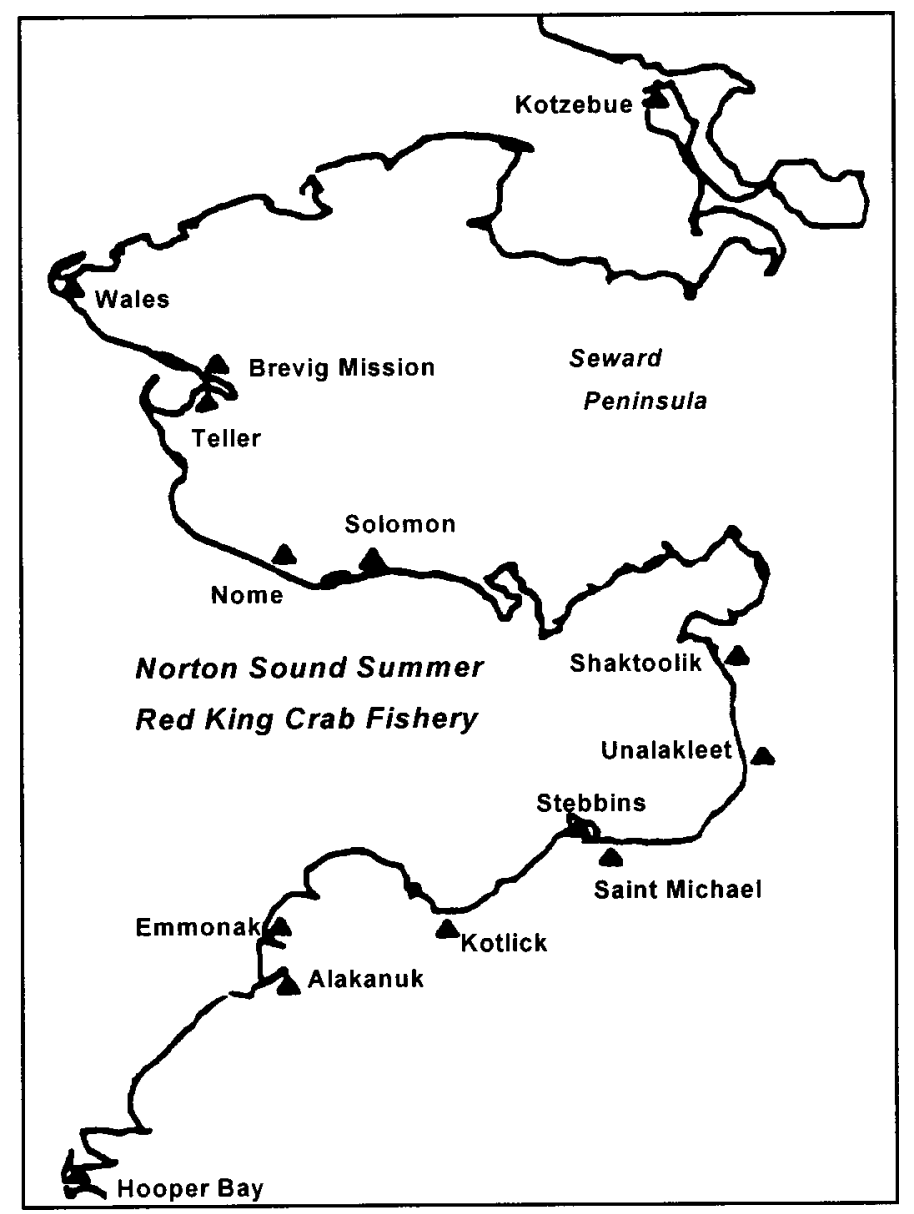

FIG. 2. Western Alaska communities and boundaries of the Norton Sound red king crab fishery.

vessel in 1992. Nome and Unalakleet had the largest number of participants in 1994 and 1995. In addition, the Yukon Delta Fisheries Corporation, a regional nonprofit community development quota (CDQ) organization, had 9 vessels participating in 1994 and 14 in 1995 (Table 1).

Since the change in regulation, the local fleet of smaller vessels has grown, while the distant-water fleet has all but disappeared. The fleet increased from 27 vessels in 1992 to 48 vessels in 1995 . The size of the vessels diminished, as did the number of pots that they carried. The typical vessel in 1992 was $36 \mathrm{~m}$ long and fished 98 pots. In contrast, the typical 1995 vessel was $9.4 \mathrm{~m}$ and fished 32 pots. Season length increased from 2 days in 1992, to 31 days in 1994 and 67 days in 1995. The increase in season length, due to an overall decrease in fishing pressure, was much welcomed by management (C. Lean, Area Biologist ADFG Nome, pers. comm. 1996).

Support industries have also developed in the region in response to localization of the fishing fleet. Approximately 36\% of the 1994 harvest and $98 \%$ of the 1995 harvest were processed in Nome. The principal local processor is owned by the Norton Sound Economic Development Corporation, a nonprofit CDQ organization. Nome has become the principal staging area for the fishery: its 
TABLE 1. Home port, average vessel length, and number of pots for vessels participating in the Norton Sound summer red king crab fishery, $1992-95 .^{1}$

\begin{tabular}{|c|c|c|c|c|c|c|c|c|}
\hline & $\begin{array}{c}\text { Nome } \\
\text { Census District }\end{array}$ & $\begin{array}{l}\text { Wade Hampton } \\
\text { Census District }\end{array}$ & $\begin{array}{c}\text { Alaska } \\
\text { Non-Local }\end{array}$ & Non-Alaska & $\begin{array}{c}\text { Total Number } \\
\text { of Vessels }\end{array}$ & $\begin{array}{c}\text { Average } \\
\text { Vessel Length }(\mathrm{m})\end{array}$ & $\begin{array}{c}\text { Average } \\
\text { Number of Pots }\end{array}$ & $\begin{array}{c}\text { Season Length } \\
\text { (Days) }\end{array}$ \\
\hline 1992 & 1 & 0 & 6 & 20 & 27 & 36 & 98 & 2 \\
\hline 1993 & 2 & 1 & 6 & 5 & 14 & 12 & 40 & 58 \\
\hline 1994 & 20 & 6 & 3 & 4 & 33 & 9 & 35 & 31 \\
\hline 1995 & 25 & 14 & 3 & 6 & 48 & 9 & 32 & 67 \\
\hline
\end{tabular}

${ }^{1}$ Source: ADFG, 1996

TABLE 2. Number of vessels from western Alaska communities participating in the Norton Sound summer red king crab fishery, $1994-95{ }^{1}$

\begin{tabular}{|c|c|c|c|c|c|c|c|c|c|}
\hline & Nome & Unalakleet & Shaktoolik & St. Michael & Stebbins & Kotlik & Alakanuk & Emmonak & Naknek $^{2}$ \\
\hline 1994 & 7 & 11 & 1 & 1 & 0 & 2 & 2 & 2 & 1 \\
\hline 1995 & 12 & 11 & 1 & 0 & 1 & 5 & 3 & 6 & 0 \\
\hline
\end{tabular}

${ }^{1}$ Source: ADFG, 1996

${ }^{2}$ Naknek is located in Kvichak Bay, approximately $794 \mathrm{~km}$ south of Nome.

local businesses provide supplies, gear, equipment, lodging, and docking facilities.

\section{THE NOME REGION}

Current participants in the NSSRKC fishery are principally from western Alaska communities located on the southern portion of the Seward Peninsula and the northwestern portion of the Yukon Delta region. The Seward Peninsula communities are located in the Nome U.S. census district and the Yukon Delta communities are located in the Wade Hampton U.S. census district. Table 2 shows the number of vessels from each of these communities in 1994-95 (See Fig. 2 for locations).

The localization of the NSSRKC fishery has had important economic impacts on communities from both census districts. However, as a result of time and fiscal constraints, the formal regional economic model developed in this study is limited to the Nome U.S. census district (Nome region). The Nome U.S. census district (rather than the Wade Hampton census district) was chosen for economic modeling because it is the home region to a majority of the fishery participants, the location of the sole local processor (in Nome), and the staging area for the summer fishery. The economic impacts presented in this paper thus represent only part of the overall economic benefits to western Alaska from localization of the NSSRKC fishery.

The Nome region shares many characteristics in common with other regions of rural Alaska. The region comprises small villages, with populations under 750 , and a single city, Nome. The region is the ancestral home of the Iñupiat- and Yupik-speaking Eskimos, and currently most of the villages have predominately Native Alaskan populations. The area is isolated by its remoteness from major urban areas of Alaska and by the absence of surface transportation systems. No road or rail corridors connect the area to other Alaska regions, and while there is a road system around the city of Nome, the roads in most villages are strictly local.

The economies of the Nome region are experiencing stagnation or even decline, which can be attributed to the lack of employment opportunities in the cash economy, a situation not atypical of the circumpolar North (Stabler, 1990). High unemployment rates in the cash sector reflect the limited number of developed industries throughout the region. The majority of jobs that do exist are directly related to government agencies and educational services. Many households in rural Alaska engage in a mixed cash/ subsistence economic strategy (Wolfe and Ellanna, 1983). Subsistence production supplements or replaces market purchases, and cash income is used to purchase necessary inputs for subsistence production. Subsistence activities, over time, have become increasingly capital-intensive (Geier et al., 1994).

The problems faced by the communities of Norton Sound are impressive - and all too prevalent in rural Alaska. The super-exclusive designation of the NSSRKC fishery has provided an economic stimulus to the regional economy, creating a new industry and encouraging further development of the region's fishing industry.

The largest community within the Nome region is Nome, which is located on the southern shore of Seward Peninsula. By air, Nome is $731 \mathrm{~km}$ from Fairbanks and $821 \mathrm{~km}$ from Anchorage. A local road system connects Nome to several other Seward Peninsula communities, but much of it is impassable except during summer. Access to Nome from outside the region is limited to air and sea transportation, and sea travel is limited to the summer months when the Sound is ice-free. 
Nome's 1994 population was 4559, of whom 52\% were Native Alaskan, $45 \%$ white, and 3\% Hispanic (NPFMC, 1994). The relatively high non-Native population reflects Nome's position as a regional center for government and commerce. Nome also has the distinction of being the focus for in- and out-migration of residents from small, subsistence-based economies (Wolfe and Ellanna, 1983). Natives travel to Nome to engage in wage employment, receive medical care, attend school, or visit relatives who reside more permanently in the community. The average residency in Nome for Native households is 26.5 years. In contrast, the average residency for non-Natives is only 9.6 years, which generally reflects the hiring of high-salaried professionals from outside the region.

Nome provides service and trade functions for about 22 communities. The major employer in Nome is government: local, state, and federal governments together accounted for 526 jobs in 1990 (NPFMC, 1994). The major industries in Nome are commerce, public administration, and mining. In 1990, retail sales provided 308 jobs followed by public administration (261 jobs) and mining (109 jobs). The Alaskan Gold Company, the largest mining company, employs 75 to 100 workers during the summer (NPFMC, 1994). With some exceptions, Nome residents are generally less dependent on subsistence activities for providing food and income than residents of surrounding communities: they spend an estimated $8 \%$ of their time harvesting subsistence resources (NPFMC, 1994).

Nome has been a principal recipient of economic activity from several sources generated by the super-exclusive designation of the NSSRKC fishery. Seven vessels from Nome participated in the 1994 directed fishery and 12 vessels participated in the 1995 NSSRKC fishery. No vessel from Nome had participated in the directed fishery prior to the super-exclusive designation.

Nome has also become the processing center for the NSSRKC fishery. The Norton Sound Economic Development Corporation CDQ group has operated the Norton Sound Crab Company in Nome since 1994. This company processed 36\% of the NSSRKC harvest in 1994 and $98 \%$ of the harvest in 1995. In 1994, the company employed approximately 75 local residents (N. Stiles, pers. comm. 1994). Prior to the super-exclusive designation of the fishery, virtually all crabs harvested in the NSSRKC fishery were processed either on board catcher-processors or outside the region.

Nome's location near the fishing grounds has led to its becoming the staging area for the fishery. Nome provides lodging, supplies, and docking facilities for local and nonlocal vessels. For example, the Yukon Delta fleet docks its vessels in Nome and purchases many supplies from local merchants. There has been discussion in Nome of expanding the city's dock to accommodate growth generated by the NSSRKC fishery (N. Stiles, pers. comm. 1994). Benefits from the fishery have even extended to the tourist industry: many restaurants feature locally caught crab, and tour operators include stops at the dock facilities on their local tours.

\section{REGIONAL ECONOMIC MODEL}

A regional economic model of the Nome census district was constructed to evaluate the economic impacts of the NSSRKC fishery. Input/output (I/O) analysis was chosen as an appropriate regional economic modeling framework. I/O models are operational tools constructed from observed economic data for a particular region (Miller and Blair, 1985). Economic activity in the region is divided into a number of industrial sectors. I/O is concerned with the flow of products from each sector considered as a producer to each sector considered as a source of demand. The flow of products is tracked in monetary terms for a specific time period.

When economic effects of some stimulation to a regional economy are examined, three types of impacts are of interest: direct, indirect, and induced effects. Direct effects are immediate effects on the local economy from a change in economic activity. For example, included under direct effects for the NSSRKC fishery would be economic impacts to the harvesting, processing, and bait and fishery supply sectors. Indirect effects are economic impacts to backward-linked industries caused by changes in input demand from directly affected sectors. For example, utilities would be a sector indirectly affected by the NSSRKC fishery. Finally, induced effects are the total income generated throughout an economy by changes in household spending patterns. The introduction of a new industry injects additional income into regional households. The induced effect captures economic activity generated through household spending of this additional income.

Two I/O models were employed in this study, IMPLAN and FEAM. IMPLAN is an I/O model originally developed by the U.S. Forest Service as a tool for supporting economic analyses within land management planning procedures (Cordell, 1992). IMPLAN is a non-survey-based regional I/O model that consists of 21 economic and demographic variables at a 528 industrial sector level for all U.S. counties. IMPLAN has two basic functions (Minnesota Implan Group, 1997). First it is used to create regional and national I/O models along with their corresponding multipliers and response coefficients. Second, the model is used to estimate regional economic impacts resulting from changes in final demand.

IMPLAN in isolation lacks sufficient detail to assess impact from shocks to the commercial fishing industry; it needs to be augmented by a more detailed representation of the industry. FEAM provides not only the additional detail for the commercial fishing industry but also a structure for organizing the impact assessment information. Moreover, this model is production-oriented and therefore can estimate the impacts of policy changes with regard to the commercial fishing industry. FEAM was developed to 
assess the impacts of commercial and recreational fishing industries on regional economies (Jensen, 1995). Through its I/O framework, FEAM uses the response coefficients and secondary economic data generated by IMPLAN to account for interlinkages in regional coastal economies through production and consumption patterns.

Within the FEAM framework, a commercial fishing industry is divided into two broad categories: suppliers (which includes crew shares[earnings], operating income to harvesters, fuel, food, and moorage) and processors. The level of production activity is transformed into industry revenues. Revenues are divided into cash flows on the basis of industry accounting models. Cash flows are then multiplied by the relevant total income response coefficients generated from IMPLAN to estimate changes in regional income from the production change.

The FEAM and IMPLAN models were adjusted to better reflect the Nome economy and NSSRKC industry. IMPLAN was "ground-truthed" through intensive interviews with area residents, business people, and government officials. For FEAM, the NSSRKC fleet was divided into four vessel categories based on vessel characteristics. Processor and harvester cost information was obtained through interviews and surveys. Expenses were categorized as local, state, or out-of-state expenditures.

\section{RESULTS}

The regional economic model arising from the IMPLAN and FEAM models was employed to estimate the actual effects of the 1994 NSSRKC fishery on the Nome regional economy. In addition, two "what if" scenarios were constructed to evaluate various harvest and processing possibilities. These scenarios were used to conduct impact analysis and to explore more fully the economic effects of the fishery on the Nome region. The baseline model was based on the actual condition of the fishery in 1994, and the impact was measured on the Nome U.S. census district. In the first scenario, the baseline model was adjusted under the assumption that the entire fishing fleet was local. This adjusted model provides a better understanding of the fishery's 1994 economic impact on western Alaska by including the Wade Hampton census district communities, which were excluded in the baseline model. The second scenario assumes a completely local fishery, i.e., it assumes that both the harvesting and the processing sectors are based solely within the Nome region. This adjustment more accurately reflects the fact that $98 \%$ of the 1995 processing took place in Nome because of the community's expanded processing capability.

\section{The Baseline Model}

The baseline scenario estimates economic impacts of the 1994 NSSRKC fishery on the basis of actual industry conditions. In 1994, the fishery harvest was $150000 \mathrm{~kg}$,
TABLE 3. Estimated economic impact of the 1994 Norton Sound summer red king crab industry on the Nome U.S. Census District.

\begin{tabular}{lcc}
\hline \hline Economic Sector & Economic Impact & Regional Total \\
\hline $\begin{array}{l}\text { Direct Sectors } \\
\text { Owners and Employees, } \\
\quad \text { Harvesting and Processing Sectors }\end{array}$ & $\$ 222539$ & \\
$\begin{array}{l}\text { Other Direct Sectors } \\
\text { Total Direct Sectors }\end{array}$ & $\$ 183203$ & \\
$\begin{array}{l}\text { Indirect Sectors } \\
\text { Induced } \\
\text { Local } \\
\quad \begin{array}{l}\text { Non-Local } \\
\text { Total Induced }\end{array}\end{array}$ & $\$ 19373$ & $\$ 19373$ \\
Regional Economic Impact & $\$ 8013$ & \\
\hline \hline
\end{tabular}

with an exvessel price of $\$ 4.45 / \mathrm{kg}$. The fishery had 34 participating vessels, 18 of which were from the Nome census district. Thirty six percent of the fishery harvest (53 $432 \mathrm{~kg}$ ) was processed in Nome. Wholesale prices received by the Nome processor were $\$ 10.47 / \mathrm{kg}$ for live crab, $\$ 11.57 / \mathrm{kg}$ for whole cooked and $\$ 15.76 / \mathrm{kg}$ for section cooked.

The results from the FEAM model are presented in Table 3. The estimated total income generated in the Nome regional economy from the 1994 NSSRKC industry was $\$ 433$ 128. The FEAM model output disaggregates the economic impact into three income components, direct, indirect, and induced. Table 3 shows that the NSSRKC fishery generated an estimated $\$ 222539$ in income to employees and owners within the commercial harvesting and processing sectors. The FEAM model categorizes participants in the commercial fishing and processing sectors as either employees or owners. Wages and salaries are distributed to the employees, while all profits are distributed in the form of income to the owners. This reported total economic impact represents a direct income flow to the regional economy from the fishery.

While income flows from the commercial fishing and processing sectors may be the most obvious direct income effect of the 1994 NSSRKC fishery, support industries such as bait and fisheries supply sectors also experienced direct income effects. The estimated economic impact to other direct sectors was $\$ 183203$. The total direct economic impact was $\$ 405742$.

The FEAM model estimates a single aggregate total indirect economic effect. For the Nome region, the indirect impact of the 1994 NSSRKC industry was estimated to be $\$ 19$ 373. Recall that indirect income effects are income changes in backward-linked industries caused by the changing inputs of directly affected industries.

The combined direct and indirect income effects of \$425 115 represent income generated within the Nome regional economy through industrial sectors that directly or indirectly support the NSSRKC industry. The Nome regional economy is further stimulated as this income flows into households, and residents acting as consumers 
purchase additional goods and services. This economic impact is referred to as the induced effect.

In formal terms, the induced income effect is the total income generated throughout an economy by changes in household spending patterns. The estimated total induced income effect from the 1994 NSSRKC industry was $\$ 34852$. Note that in Table 3, the induced income effect is divided into two components. The first component, total local purchases, was estimated to be $\$ 8013$. This represents the amount of income generated to the Nome regional economy from local purchases of goods and services by consumers. But local consumers also spend a portion of their income outside the Nome region. The estimated income generated from non-local purchases of goods and services was \$26 839. Income generated from non-local purchases accrues to residents outside the Nome regional economy. Accordingly, this income source is not included as an economic impact to the Nome regional economy.

\section{Scenario 1: Local Harvesting Sector}

In this scenario, the regional economic model was adjusted to investigate what the economic impact would have been to the Nome region had the entire fishing fleet originated from the Nome region. This scenario was modeled to provide a more comprehensive examination of the impacts the NSSRKC industry has had on Western Alaska. Vessels originating from the Wade Hampton U.S. census district in the 1994 fishery were not included as local vessels in the baseline case; yet income generated from these vessels does accrue to Western Alaska and, accordingly, is of interest to this study.

The model results for Scenario 1 are presented in Table 4. The total regional economic impact was an estimated $\$ 544222$. This represents a $25.6 \%$ (\$111 094) increase in regional income over the baseline case. Income to direct sectors was estimated to be $\$ 507664$, a $25.1 \%$ increase from the baseline case. This increase resulted from use of local crews on vessels and from accrual of fishery profits to local residents. Localization of the harvesting sector also generated an estimated indirect income of $\$ 43674$, a $36.8 \%$ increase from the baseline case. Finally, the local induced effect rose to $\$ 10045$.

\section{Scenario 2: Local Harvesting and Processing Sectors}

Scenario 2 estimates what the economic impact to the Nome regional economy would have been if the fishery had been entirely local, i.e., completely local harvesting and processing sectors. It is estimated that under these conditions, the 1994 NSSRKC industry would have generated $\$ 922500$ in income to the Nome regional economy, a $129.9 \%$ increase from the baseline case (Table 5). This scenario most closely reflects current industry conditions with respect to the economic contribution of the NSSRKC industry to the Nome region and Western Alaska. As noted, the vast majority of the fleet is currently from
TABLE 4. Scenario 1, estimated 1994 Norton Sound summer red king crab industry economic impact with local harvesting sector.

\begin{tabular}{|c|c|c|}
\hline Economic Sector & Economic Impact & Regional Total \\
\hline \multicolumn{3}{|l|}{ Direct Sectors } \\
\hline \multicolumn{3}{|l|}{ Owners and Employees, } \\
\hline Harvesting and Processing Sectors & rs $\$ 290705$ & \\
\hline Other Direct Sectors & $\$ 216959$ & \\
\hline Total Direct Sectors & & $\$ 507664$ \\
\hline Indirect Sectors & $\$ 26513$ & $\$ 26513$ \\
\hline \multicolumn{3}{|l|}{ Induced } \\
\hline Local & $\$ 10045$ & $\$ 10045$ \\
\hline Non-Local & $\$ 33629$ & \\
\hline Total Induced & $\$ 43674$ & \\
\hline \multicolumn{2}{|l|}{ Regional Economic Impact } & $\$ 544222$ \\
\hline
\end{tabular}

TABLE 5. Scenario 2, estimated 1994 Norton Sound summer red king crab industry economic impact with local harvesting and processing sectors.

\begin{tabular}{lcc}
\hline \hline Economic Sector & Economic Impact & Regional Total \\
\hline $\begin{array}{l}\text { Direct Sectors } \\
\text { Owners and Employees, } \\
\quad \text { Harvesting and Processing Sectors }\end{array}$ & $\$ 617057$ & \\
$\begin{array}{l}\text { Other Direct Sectors } \\
\text { Total Direct Sectors }\end{array}$ & $\$ 244350$ & \\
$\begin{array}{l}\text { Indirect Sectors } \\
\text { Induced } \\
\text { Local } \\
\quad \text { Non-Local } \\
\quad \text { Total Induced }\end{array}$ & $\$ 44048$ & $\$ 861407$ \\
Regional Economic Impact & $\$ 17045$ & $\$ 17048$ \\
\hline \hline
\end{tabular}

communities in Western Alaska, and almost all of the fishery harvest was processed in Nome in 1995.

In this scenario, the direct income of owners and employees in the processing and harvesting sectors rose to an estimated $\$ 617057$, a $\$ 394518$ increase from the baseline. The estimated total direct income effect increased by $112.3 \%$ to $\$ 861407$. The indirect income effect increased by $127.4 \%$ to $\$ 44048$, and the local induced effect rose to $\$ 74107$, a $54.1 \%$ increase.

\section{CONCLUSIONS}

The super-exclusive designation of the NSSRKC fishery has represented an important development in Alaska fishery management. The fishery was previously beset with an impressive series of problems, including overcapitalization, lack of management precision, and safety concerns. The chosen management option alleviated many of these problems by downsizing the fishing fleet. Not only has this change in policy achieved management's objectives, but it has also led to significant economic development in an economically depressed region of Alaska. The fishery has provided important employment 
opportunities to local residents and has served as the basis for new business development.

The results from the FEAM model indicate that the 1994 NSSR KC fishery generated an estimated \$433132 of additional income in the Nome regional economy. This value represents income flowing directly to the residents of the Nome region from the harvesting of $147536 \mathrm{~kg}$ of red king crab with an exvessel value of $\$ 4.45 / \mathrm{kg}$ and the local processing of $53432 \mathrm{~kg}$. Moreover, a total income multiplier of 1.39 was estimated from these results. That is, for every $\$ 1$ of output generated in the harvesting of NSSRKC, $\$ 1.39$ of regional income is generated. Although this amount is substantial for Nome, it represents only a portion of the total income generated from the 1994 NSSRKC fishery. Two factors kept part of the total income from being realized in the Nome region. First, non-locals participated in the fishery and subsequently purchased goods and services outside the region. Moreover, their vessels hired non-local crew members. Second, $64 \%$ of the harvest was processed outside the region.

To estimate the regional economic impact of the fishery without those two factors, i.e., with no income leakage, two different harvesting and processing scenarios were developed. The localized fleet scenario estimated that $25 \%$ more local income would have been generated from the 1994 NSSRKC industry if all vessels had originated from the Nome region. This estimate was performed to capture the effect of including the Wade Hampton census district in the local economy.

The scenario that estimated the additional impact of having the entire harvest processed locally is also relevant to the current fishery. Since $98 \%$ of the 1995 harvest was processed in Nome, this scenario reflects current processing activity. When this scenario was used in the model, the NSSRKC industry generated nearly $\$ 1$ million in regional income. Moreover, estimated income to fishery participants increased by $177 \%$ over the baseline 1994 case. It is important to note that this estimate is based on the 1994 exvessel price of $\$ 4.45 / \mathrm{kg}$. In fact, the 1995 exvessel price increased to $\$ 6.32 / \mathrm{kg}$. This scenario therefore represents a conservative estimate.

The model shows that the 1994 NSSRKC industry generated substantial income in the Nome region. Through a change in management policy, an industry in its infancy was able to contribute over half a million dollars in income to an economically depressed region of Alaska where few local industries exist and the prospects for developing new industries are dim. Furthermore, model results suggest that actual local regional economic contributions nearly double when the Wade Hampton census district is included and the processing sector is assumed to be entirely local, as it essentially was by 1995 .

\section{ACKNOWLEDGEMENTS}

We acknowledge and thank the National Marine Fisheries Service and the Alaska Department of Fish and Game for financial support. Dr. Earl Krygier and Mr. Ken Griffith of the Fisheries Management and Development Division of the Alaska Department of Fish and Game provided assistance and information. The assistance of Mr. Charlie Lean of the Alaska Department of Fish and Game, Mr. Norm Stiles of Nome, Alaska, Mr. William Jensen of Jensen and Associates, Mr. Ed Glofelty of the Yukon Delta Fisheries Development Association, and Mr. John Zuck of the Norton Sound Economic Development Corporation is also appreciated. This is Alaska Agricultural and Forestry Experimental Station Paper No. J-98-2.

\section{REFERENCES}

(ADFG) ALASKA DEPARTMENT OF FISH AND GAME. 1994. Fishery management plan for Norton Sound section, red king crab. Anchorage, Alaska.

1996. Norton Sound summer commercial red king crab fishery observer project summary report 1995. Anchorage, Alaska.

CORDELL, H.K., BERGSTROM, J.C., and WATSON, A.E. 1992. Economic growth and interdependence effects of state park visitation in local and state parks. Journal of Leisure Research 24(3):253-268.

GEIER, H., GREENBERG, J.A., and HERRMANN, M. 1994. Subsistence fisheries in Alaska: Conflicts within a multiple use resource. In: Antona, M., Catanzano, J., and Sutinen, J.G., eds. Proceedings of the Sixth Conference of the International Institute of Fisheries Economic and Trade. 1212-1219.

JENSEN, W. 1995. Commercial fisheries economic assessment model. William Jensen Consulting Group. Vancouver, Washington: RVI Software.

MILLER, R.E., and BLAIR, P.D. 1985. Input-output analysis: Foundations and extensions. Englewood Cliffs, New Jersey: Prentice-Hall, Inc.

MINNESOTA IMPLAN GROUP. 1997. IMPLAN professional: Social accounting and impact analysis software. Stillwater, Minnesota: Minnesota Implan Group.

(NPFMC) NORTH PACIFIC FISHERIES MANAGEMENT COUNCIL. 1989. Fishery management plan for the commercial king and Tanner crab fisheries in the Bering Sea/Aleutian Islands. Anchorage, Alaska.

.1994. Faces of the fisheries, western Alaska. Anchorage, Alaska.

STABLER, J.C. 1990. A utility analysis of activity patterns of Native males in the Northwest Territories. Economic Development and Cultural Change 39(1):47-60.

WOLFE, R.J., and ELLANNA, L.J. 1983. Resource use and socioeconomic systems: Case studies of fishing and hunting in Alaskan communities. Juneau, Alaska: Alaska Department of Fish and Game, Division of Subsistence. 